\title{
THE EFFECT OF POLYPROPYLENE PLASTIC RESIDUE ON HEATED PALM OIL AGAINST HISTOPATHOLOGICAL CHANGES OF SMALL INTESTINE ON MALE WHITE RAT (Rattus norvegicus) WISTAR STRAIN
}

\author{
Aulia Puspa Amaris 1), Lita Rakhma Yustinasari 2), Djoko Legowo 2), \\ Hani Plumeriastuti 2), Chairul Anwar 2), Nove Hidajati 2) \\ 1) Mahasiswa, 2) Dosen \\ Fakultas Kedokteran Hewan Universitas Airlangga \\ Kampus C UNAIR, Jl. Mulyorejo-Surabaya 60115 \\ Telp. 031-5992785, Fax. 031-5993015 \\ Email: jbmvunair@gmail.com
}

\begin{abstract}
This study was conducted to investigate the effect of polypropylene residue on heated palm oil against histopathological changes of small intestine on male white rat (Rattus norvegicus) wistar strain. Eighteen male white rats divided into three groups and were administered via peroral gavage with different treatments for five weeks. The treatment were Control (84 grams palm oil), P1 (84 grams palm oil with 2.3 grams plastic), and P2 (84 grams palm oil with 6.81 grams plastic). The histopathological changes of small intestine were examined by using Barthel Scoring method was analysed using Kruskal Wallis and continued with MannWhitney test. The result showed that were significant difference $(p<0.05)$ between treatment groups. The worse damage of polypropylene plastic residue was 6.81 grams.
\end{abstract}

Key words: Polypropylene plastic, palm oil, Rattus norvegicus, small intestine

\section{INTRODUCTION}

In Indonesia there are many misapplication of plastic that is used in frying food. Plastic is put into hot oil which is then used for frying, then the volatile plastic properties will enter into the food and cause problems in the body. The addition of plastic to palm oil used for frying is aimed so that the food produced remains crunchy and looks fresh for long time (Sari et al., 2017).

The phenomenon that emerged in the community was then scientifically proven by screening conducted in Medan, North Sumatra. The research used Qualitative Description method. Beginning with collecting sample at 15 fried sellers randomly. Every fried seller taken four sample form fried banana, fried tempe, fried tofu and fried bakwan. Samples that have been collected and then tested by burned. If the sample burns $\pm 40-50 \%$ and produces black droplet then the sample is positively contaminated with plastic material. From the 60 samples showed that $5 \%$ fried bakwan and $15 \%$ fried tempe have plastic indication. (Sari et al., 2017).

The plastic is a synthetic polymer or thermoplastic polymer (polymer which will be softened if heated) originated from gas which then undergoes polymerization. In this process, no all gas can be formed into polymer so some of the trapped gases are not bind and cannot get out. This substance is easy to evaporate when in contact with a high temperature object. Evaporation results then enter into the water, oil, or anything that contact directly with plastic. When the substance comes in metabolism and accumulate in the body, the possibility of developing cancer will be greater (Ryosa et al, 2017).

Based on Galloway (2015), exposure to plastic residues can provide various adverse effects to the body especially to the gut. This is because the 
intestines are organs that contact directly to the plastic particles that enter through the food and the particles will be absorbed through the intestine. Nanoparticles produced by such plastic residues can also interfere with metabolism and can cause toxins to the body. Nanoparticles are predicted to adsorb macromolecules such as proteins and lipids from the surrounding onto their surface, in a process influenced by surface energy, charge and specific affinity for certain biomolecules.

Ryosa et al (2017) found four plastic compounds on many fried food sample: Benzene, acrylic acid decyl ester, Trans-3,5-Dideutero hydroxycyclopentene, and Cyclohexan 1,2,3,5-tetraisopropyl. Benzene is a wellestablished cause of cancer in humans. Benzene causes acute myeloid leukaemia (acute non-lymphocytic leukaemia), and there is limited evidence that benzene may also cause acute and chroniclymphocytic leukaemia, non-Hodgkin's lymphoma and multiple myeloma. Individuals who have experienced benzene poisoning requiring treatment show a substantially increased risk of mortality from leukaemia (WHO, 2010). Acrylic acid decyl ester can caused abdominal cramps, burning sensation and diarrhea (PubChem, 2005). The effect on the body both Trans-3,5-Dideutero hydroxycyclopentene and Cyclohexan 1,2,3,5tetraisopropyl are not yet known.

Plastics that enter the body have been melted with oil and form chemical compounds. Benzene is one of these chemical compounds. When benzene enters the body it can produce reactive oxygen species (ROS) (Falzone et al., 2016). With the presence of ROS it can trigger irritation in cells, especially in small intestinal epithelial cells (Balmus et al., 2016).

There are several types of
inflammatory cells: neutrophils,
eosinophils, basophils, lymphocytes,
monocytes, and plasma cells.

Inflammatory cells act as an immune component that functions as phagocytes (Arimbi et al., 2014).

The intestinal epithelium is covered by a simple cylindrical epithelium with goblet and striated border cells. According to Mescher (2007), the columnar epithelium that covers intestinal villi consists mainly of the tall absorptive enterocytes. The apical ends of these cells are joined and covered by a striated border of microvilli. Covered by a coating of glycoproteins, the striated border, along with the mucus-secreting goblet cells.

\section{RESEARCH MATERIAL AND METHOD}

\section{Material and Equipments}

Animal Experiments that used in this study were 18 male white rats. The white rats originated from Veterinaria Farma Center (PUSVETMA), Surabaya. The palm oil have been obtained from local supermarket. Feed using pallets obtained from Bird Market, Bratang, Surabaya. Drinking water using gallon water.

The equipment that used in this research are 6 plastic cages size $40 \times 30 \times 16 \mathrm{~cm}$ with a drinking bottle on each cage, placed on laboratory with normal room temperature $\left( \pm 24^{\circ} \mathrm{C}\right)$. The feed and drink will given ad libitum.

Other tools that used are scalpels and sterile blades, forceps and surgical instruments for dissecting animals and by passing small intestine. A series of dehydrated apparatus, oven, microtome, water bath, hotplate, staining jar, object glasses, cover glasses, and labels are used to make histopathologic preparations. Microscope and camera are required to check and document preparations.

This research using male wistar strain white rats (Rattus norvegicus) as many as 18 rats randomized to three treatment P0, P1, and P2. each treatment uses six rats. Rats began to be 
maintained with one weeks adaptation time. The rats began to be treated at the third weeks and kept for five weeks.

\section{Research Plan}

This research using Completely Randomized Design. In this design there is only one source of variability, that is the random effect of treatment on the mice, so the different result of the treatment only caused by the treatment's effect and random effect. Then this research using three groups and six replicates for each group.

\section{Treatment}

Rats (Rattus norvegicus were captived in rat cage placed in Laboratory of Experimental Animal at the Faculty of Veterinary Medicine Universitas Airlangga, randomized and devided into three groups. Then were adapted to the environment for one week, After the adaptation period, the treatment group was given with oil containing polypropylene plastic residue by oral for five weeks. The treatment explained as follows:

a. $\mathrm{P} 0=84$ grams palm oil

b. $\mathrm{P} 1=84$ grams palm oil +2.3 grams plastic

c. $\mathrm{P} 2=84$ grams palm oil +6.81 grams plastic

After 24 hours from the last treatment, treatment groups of P0, P1, and P2 are sacrificed by cervical dislocation method and the small intestine of rats collected.

\section{Microscopic Examination}

Examinations include scoring of epithelial damage and inflammatory cells infiltration to lamina propia. The examinations was conducted as many as five field views with 400x magnification in each slide and in one field of view was given a score according to Barthel $e t$ al. (2003). After the changes being scored, the epithelial damage score summed with inflammatory cells infiltration score to get the total score.

\section{Data Analysis}

The result of this research is semiquantitative so that the scoring data will be analyzed using Kruskal-Wallis test then continued with Mann-Whitney U test to see differences among groups. The analysis used Statistical Package for the Social Sciences (SPSS) 21 program.

\section{RESEACH RESULT}

$\begin{array}{ccr}\text { The observation } & \text { of } \\ \text { histopathological preparation were }\end{array}$ using Hematoxylin Eosin (H\&E) staining. Examination on five fields of view randomly per areas, using microscope with 100x times magnification, then continued with $400 x$ times magnification. Histopathological changes in small intestine that have been observed are damages to epithelial cells and determination of inflammatory cells.

The results obtained from observations and assessments of each treatment were processed by Statistical Programs and Social Scientific (SPSS) using the Kruskal Wallis test. Based on these tests if there are significant differences $(p<0.05)$ then the Mannhitney $U$ test is needed. The results of the small intestine damage score data are in the following table :

Table 1. The results of the small intestine damage changes of rats (Rattus norvegicus)

\begin{tabular}{|c|c|}
\hline Treatment & $\begin{array}{c}\text { Small Intestine } \\
\text { Damage (Median) }\end{array}$ \\
\hline P0 & $4.80^{\mathrm{a}}$ \\
\hline P1 & $5.50^{\mathrm{b}}$ \\
\hline P2 & $5.90^{\mathrm{b}}$ \\
\hline
\end{tabular}

Different supercript in the same column indicate significant differences $(p<0.05)$ 

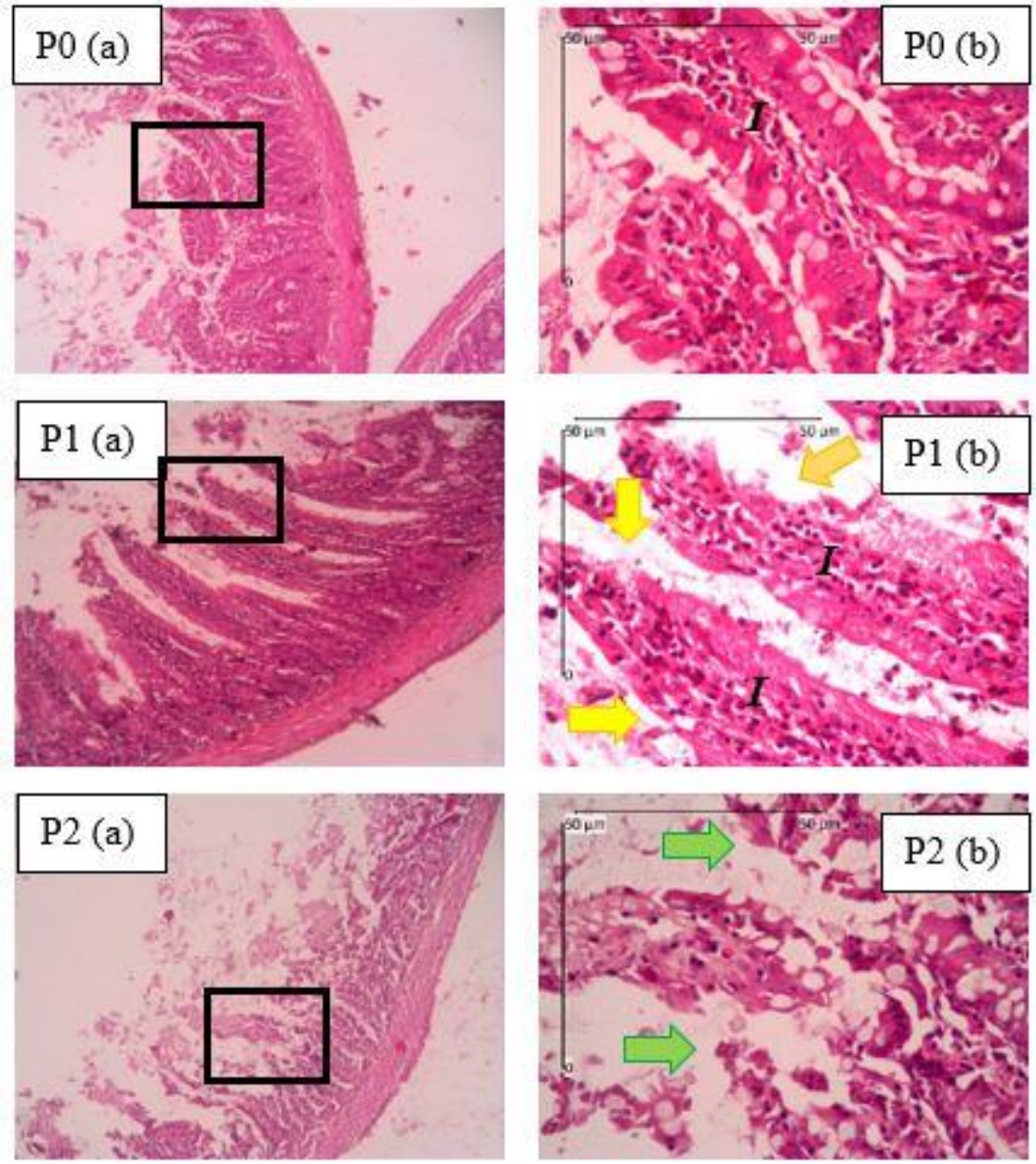

Figure 1. Histopathological changes of small intestine in rats, H.E staining 100x magnification (a), 400x magnification (b) with Optilab® viewer. Yellow arrow showed epithelial desquamation, green arrow showed erosion of the epithelial, and (I) showed inflammatory cells infiltration.

The results of the analysis data using Kruskal Wallis value $\mathrm{p}=0.016(\mathrm{p}<0.05)$. This shows that the treatment gets the results of significantly different effects on the histopathology of the small intestine in white rats, so it is continued with the Mann-Whitney $U$ test. The results of Mann-Whitney $U$ test are treatment group P0 significantly different from P1 and P2. Treatment group P1 was significantly different from $\mathrm{P} 0$, but not significantly different from P2. Treatment group P2 was significantly different from $\mathrm{P} 0$, but not significantly different from P1. During the experiment there were several changes that occurred in experimental animals. The rats in all treatments experienced a significant increase in body weight from the first week of treatment until the fifth week of treatment. At the end of the first week the rats began to diarrhea, but until the end of the experiment there was no bloody diarrhea. The control group only experienced normal diarrhea with normal color and smell, and the consistency of feces which was still denser compared to groups P1 and P2. In group $\mathrm{P} 1$ there was diarrhea with a softer consistency compared to the control group. The feces color also looks 
paler compared to the control group. In group P2 diarrhea and faecal color were yellowish white and paler with a more pungent odor compared to P0 and P1.

\section{DISCUSSION}

Plastics that are heated together with palm oil can produce several dangerous chemical components. Research result showed that treatment group P0 have a significant difference with P1 and P2 group, but treatment group P1 did not have a significant difference with P2 group (Table 1). It showed the evidence of small intestine damage caused by polypropylene plastic residue exposure.

The oil mixed with plastic enters the body through the mouth will pass through the stomach. In the stomach the oil will be digested by the lipase enzyme. After that the oil will be digested in the small intestine. In the duodenum there is an estuary of the choledocyst duct and pancreatic duct. Bile fluid is released through the choledococcal duct, while pancreatic fluid is released through the pancreatic duct. Oil after being emulsified by bile salts becomes water-soluble, allowing the pancreatic lipase enzyme to work. The pancreatic lipase enzyme plays an important role in the digestion of fat in the small intestine as a breakdown of bonds between fatty acids with glycerol in chains 1 and 3 of triglycerides so that fatty acids and monoglycerides are produced. Fatty acids, glycerol, and cholesterol in the lumen of the small intestine unite to form granules (aggregates) called micelle (Nurcahyo, 2005). Micelle is small spherical cylindrical lumps 3 to 6 nanometers in diameter consist of 20-40 molecules of bile salt. This micelle is formed because each molecule of bile salt is composed of a very fat-soluble sterol nucleus and a polar group that is very water-soluble. The sterol nucleus forms small fat clumps in the middle of the micelles that have formed with polar groups of bile salts that protrude out to cover the surface of the micelles. Because this negatively charged group allows all micelles to dissolve in the digestive juices and remain stable until the fat is absorbed into the blood. Micelles also act as a transport medium to transport monoglycerides and free fatty acids to brush border intestinal epithelial cells to be absorbed into the blood (Guyton, 2008).

Damage that occurs in P1 and P2 are thought to occur due to the large number of plastic particles and cannot be digested by the intestine. The chemicals produced by polypropylene plastic which are heated together with oil are hydrophobic while the small intestine is hydrophilic, so the chemicals will be difficult to digest by the small intestine. This inability of villi to digest chemical subtances that produced by heated plastics can causes irritation of the intestine which is seen by damage to the small intestine villi in the form of desquamation and erosion. Long-term irritation can result disruption of the digestive process (Siagian, 2016).

Based on Ryosa et al. (2007), benzene is one of the chemical subtances that can be found in fried food that fried with oil contain polypropylene plastic. Epidemiological and experimental studies have suggested that the exposure to benzene can cause a great number of acute and chronic diseases, which can involve several human tissues or organs (Falzone et al., 2016).

Several potential mechanisms of benzene toxicity have been proposed. It is generally recognized that its metabolism is critical in the toxicity, with the involvement of one or more reactive metabolites, which are further bioactivated by myeloperoxidases and other heme-protein peroxidases to the reactive compounds emiquinones and quinones. These reactive products can lead to the formation of reactive oxygen species (ROS), which can directly 
damage pivotal molecular targets, such as DNA, lipids and proteins, leading to the formation of new compounds and modified structures, as advanced oxidation protein products (AOPP), advanced glycation end-products (AGE) and advanced lipoperoxidation endproducts (ALE) (Falzone et al., 2016). With the formation of ROS it can cause stress to the mitochondria and can interfere with the metabolic process in the cell which triggers irritation in cells which, if they occur for a long time, can cause apoptosis (Balmus et al., 2016).

$$
\text { Based on Corwin (2008), }
$$
inflammatory can be caused by chemical components, microorganisms, mechanical trauma, and physics influence. The ultimate goal of the inflammatory response is withdraw plasma proteins and phagocytes to the place of injury or invaded to be able to isolate, destroy, or activate incoming agent, cleans debris and prepares tissue for the healing process.

ROS is the trigger for the preparation and activation of the inflammatory system which is a cytoplasmic multiprotein complex involved in the mediation of inflammatory cells so that it is able to respond to several destructive agents. Mitochondria are believed to be the main source of activating the inflammatory system based on ROS, although there are other sources. Apart from causing the activation of the inflammatory system, ROS also plays a role in inhibiting the mitophagy process, which is the process of removing damaged mitochondria. Therefore, mitochondrial damage will continue without the removal of damaged mitochondria, so that the production of ROS increases and continues to affect the inflammatory process. Cells containing damaged mitochondria may be able to experience apoptosis (Alfadda et al., 2012)

The presence of irritant or tissue injury will trigger the release of mediators inflammation. This compound can cause short vasoconstriction in the arterioles followed by dilation of blood vessels, venules and lymph vessels and can increase vascular permeability in cell membranes. Increased permeability Local vascular effects are influenced by complement through classical pathways (complex antigen-antibody), mannose binding lectin or alternative pathways. Increased local vascular permeability occurs with the influence of anaphylatoxin (C3a, C4a, C5a). Complement activation of $\mathrm{C} 3$ and $\mathrm{C} 5$ produces small fragments of $\mathrm{C} 3 \mathrm{a}$ and C5a Anaphyltoxin which can stimulate degranulation of mast cells and basophils for releasing histamine. Histamine released by mast cells on the influence of complement, increase vascular permeability and smooth muscle contraction, giving way to migration of leukocyte cells and the release of plasma which contains a lot of antibodies, opsonin and complement to the peripheral tissues where inflammation occurs (Abbas et al., 2010). Complement activation of C3a, C5a and C5-6-7 can attract and mobilize cells phagocytes are both mononuclear and polymorphonuclear. C5a is chemoactivity for neutrophils which are also anaphylactoxins. Activated macrophages release various mediators that play a role in inflammatory reactions. Some hours after vascular changes, neutrophils attach to endothelial cells and migrate out the blood vessels to the tissue cavity, eat pathogens and release the mediator which plays a role in the inflammatory response. Network macrophages that are activated will release cytokines including IL-1 (interleukin-1), IL-6 and TNF-a (tumor necrosis factor-a) which induces local and systemic changes. The three cytokines induces coagulation. IL1 will induce the expression of adhesion molecules in cells endothelial whereas TNF-a will increase the expression of 
selectin-E later induces an increase in excretion of intracellular adhesion molecule-1 (ICAM-1) and vascular cell adhesion molecule-1 (VCAM-1). Neutrophils, monocytes and lyphocytes recognize the adhesion molecule and move to the blood vessel wall then move towards the network. IL-1 and TNF-a also play a role in promoting macrophages and endothelial cells to produce chemokines that contribute to neutrophil influx through increasing the expression of adhesion molecules. IFN- $\gamma$ (interferon- $\gamma$ ) and TNF- $\alpha$ will activate macrophages and neutrophils which can increase phagocytosis and release of enzymes into the tissue cavity (Abbas et al., 2010).

During the inflammatory response many chemical mediators are present released locally, including histamine, 5hydroxytryptamine $(5 \mathrm{HT})$, chemotactic factors, bradykinin, leukotrienes and prostaglandins (PG). With migration of phagocytic cells to this area, lysozyme membrane lysis occurs breakdown of the enzyme (Wilmana, 2007).

\section{CONCLUSION}

Based on this research it could be concluded that polypropylene plastic residue exposure caused a significant damage for the histopathological changes on small intestine of white rats.

\section{REFERENCES}

Abbas, A.K., Lichtman, A.H., \& Pillai S., 2010, Celullar and Molecular Immunology, 6th Ed., W.B Saunders Company, Philadelphia.

Alfadda, A.A., Sallam, R.M. 2012. Reactive Oxygen Species in Health and Disease. Natl. Med. J. India. 13(6):304-310.
Arimbi, Azmijah A, Darsono R, Plumeriastuti H, Widiyatno T.V., Legowo D. 2014. Buku Ajar Patologi Umum Veteriner Edisi 2. Airlangga University Press. Surabaya.

Badan Pengawasan Obat Dan Makanan Republik Indonesia. 2016. Plastik sebagai kemasan pangan. Jakarta : BPOM RI.

Balmus, I.M., Alin, C., Carol S. 2016. The Implications of Oxidative Stress and Antioxidant Therapies in Inflammatory Bowel Disease: Clinical Aspects and Animal Models. Saudi J Gastroenterol. 2016 Jan-Feb; 22(1) 3-17

Bickley, L.S., and Szilagyi, P.G. 2006. Physical Examination and History Taking, 9th ed. Philadelphia: Lippincott Williams \& Wilkins.

Brody, A.L. 1972. Aseptic Packaging of Foods. Food Technology. Aug. 7074.

Charan, J., Kantharia N. D.. 2013. How to calculate sample size in animal studies. J Pharmacol Pharmacother. 2013 Oct-Dec; 4(4): 303-306.

Chave, L. 2007. Animal Research Review Panel Guideline 20: Guidelines for the Housing of Rats in Scientific Institutions. Animal Welfire Branch, Sydney. Page 15.

Corwin, E.J., 2008. Handbook of Pathophysiology 3th edition. Philadelphia: Lippincort Williams \& Wilkins. 
Falzone, L., Andrea, M., Carla, L., Sabrina, F., Demetrios, A.S., Massimo, L. 2016. Occupational Exposure to Carcinogens: Benzene, Pesticides and Fibers. Molecolar Medicine Reports 14: 4467-4474

Fitria, L., Mulyati, Tiraya,C.M. and Budi,A.S. 2015. Profil Reproduksi Jantan Tikus (Rattus norvegicus Berkenhout, 1769) Galur Wistar Stadia Muda, Pradewasa, dan Dewasa. Jurnal Biologi Papua Volume 7 (1) : 29-36.

Galloway, T.S. 2015. Micro-and NanoPlastics and Human Health. Marine Anthropogenic Litter.

Garrett, N. L., Lalatsa, A., Uchegbu, I., Schätzlein, A., \& Moger, J. 2012. Exploring uptake mechanisms of oral nanomedicines using multimodal nonlinear optical microscopy. Journal of Biophotonics, 5, 458-468.

Guinan, J.J. 2006. Olivocochlear Efferents: Anatomy, Physiology, Function, and the Measurement of Animal. Ear \& Hearing 27,589-607.

Guyton, A.C, Hall JE. 2008. Buku ajar fisiologi kedokteran, edisi ke-11. Jakarta: EGC.

Hestianah, E.P., Anwar,C., Kuncorojakti,S., Yustinasari,L.R., 2013. Buku Ajar Histologi Veteriner Jilid 2. Airlangga University Press. Surabaya.

Institute of Medicine. 2003. Gulf War and Health Volume 2: Insecticides and Solvents. The National Academies Press.
Juarnida. 2014. Mengidentifikasi Kandungan Plastik dalam Makanan Gorengan pada Sampel Simulasi [Skripsi]. Program Studi Pendidikan Kimia. Fakultas Keguruan dan Ilmu Pendidikan. Universitas Syiah Kuala.

Junquiera, and Carneiro. 2007. Basic Histology. The McGraw-Hill Companies.

Kusriningrum, R.S., 2008, Buku Ajar Perancangan Percobaan. Fakultas Kedokteran Hewan Universitas Airlangga, Dani Abadi, Surabaya.

LaRegina, M.C., dan Sharp, P.E. 1998. The Laboratory Rat: A Volume in the Laboratory Animal Pocket Reference Series. CRC Press, USA. Pages 1, 9, 17-18, and 87-88.

Li, C.W., Nassir, F., Zhong, Y.L., Kuo, F., Crowell, T., Olson, D., Davidson, N.O., Burkly, L.C. 2002. Disruption of hedgehog signaling reveals a novel role in intestinal morphogenesis and intestinalspecific lipid metabolism in mice. Gastroenterology. 122:469-482.

Mescher, A.L. 2007. Junqueira's Basic Histology Text \& Atlas, 12th ed. United States: Lange.

Mustika, Ade. 2014. Pengaruh Pemberian Minyak Jelantah Terhadap Gambaran Histopatologi Usus dan Pankreas Tikus Putih (Rattus norvegicus) [Skripsi]. Fakultas Kedokteran Hewan. Universitas Syiah Kuala Aceh. 
Narayan R. 1996. Biobased and Biodegradable Plastic. http://www.plasticsindustry.org / files/ events/pdfs/bio-narayan061906.pdf. [Retrieved: 24 March 2018]

Nurcahyo, H. 2005. Sistem Pencernaan Makanan (Digesti). http://staff.uny.ac.id/sites/defau lt/files/tmp/SistDigestiSMAKlsn05.pdf. [Retrieved : 28 November 2018]

Okamoto, R., Watanabe, M. 2004. Molecular and clinical basis for the regeneration of human gastrointestinal epithelia. Journal of Gastroenterology, 39:1-6

Oxtoby, D. W., Gillis H. pat, Campion, A. 2003. Principles of Modern Chemistry (7th ed.). Thomson Brooks/Cole. Publication Date: May 31, 2011. ISBN-13: 9780840049315.

PubChem. 2005. Decyl Acrylate. https:/ / pubchem.ncbi.nlm.nih.go v/compound/decyl_acrylate\#sect ion=Top. [Retrieved : 11 April 2018]

Putri, G.S. 2018. Mikroplastik Masuk Tubuh, Ini yang Bakal Terjadi Menurut Ahli. https://sains.kompas.com/read/ 2018/03/16/210100323/mikroplas tik-masuk-tubuh-ini-yang-bakalterjadi-menurut-ahli. [Retrieved: 31 March 2018]

Rowland, N.E. 2007. Food or Fluid Restriction in Common Laboratory Animals: Balancing Welfare Considerations with Scientific Inquiry. American Association for Laboratory Animal Science, 57(2): 149-160.
Ryosa, M.G., Alioes, Y., Kadri, H. 2017. Screening Kandungan Plastik pada Minyak Goreng yang Digunakan pada Jajanan Pecel Lele. Jurnal Kesehatan Andalas, 2017; 6(1)

Sari, A.R., Alioes.Y, dan Semiarty, R. 2014. Screening Kandungan Plastik pada Minyak Goreng yang Terdapat pada Gorengan di Jati Padang. Jurnal FK UNAND 2014; 3(3): halaman 358-364.

Sari, D., Riyanto. Karim, A. 2017, Kontaminasi Bahan Plastik Pada Jajanan Pasar (Gorengan) yang Beredar di Kota Medan, BioLink, Vol. 4 (1): 19-23

Seeley, R.R., et al. 2007. Anatomy and Physiology, 8th ed. New York: McGraw-Hill Book Co.

Siagian, Y.A. 2016. Gambaran Histologis dan Tinggi Vili Usus Halus bagian Ileum Ayam Ras Pedaging yang diberi Tepung Daun Kelor (Moringa oleifera) dalam Ransum [Skripsi]. Program Studi Pternakan. Fakultas Peternakan. Universitas Hasanuddin.

Sirois, M. 2005. Laboratory Animal Medicine: Principles and Procedures. Mosby, Inc. United States of America. Pages 43-45.

Sloane, E. 2004. Anatomi dan Fisiologi Untuk Pemula. Jakarta: EGC.

Smith, J.B., dan Mangkoewidjojo, S. 1988. Tikus Laboratorium (Rattus norvegicus): Pemeliharaan, Pembiakan dan Penggunaan Hewan Percobaan di Daerah Tropis. Universitas Indonesia Press, Jakarta. Halaman ix, xviixix, 37- 57. 
Snell, R.S. 2006. Anatomi Klinik Untuk Mahasiswa Kedokteran Edisi ke-6. Jakarta: EGC.

Soják, L., Kubinec, R., Jurdáková, H., Hájeková, E., Bajus, M. 2006. GCMS of Polyethylene and Polypropylene Thermal Cracking Products. Petroleum \& Coal 48 (1),1-14. ISSN 1337-7027.

Standring, S. Gray's. 2005. Anatomy: The Anatomical Basis, 39th ed. New York: Churchill Livingstone, Inc.

Syarief, R., S. Santausa, St. Ismayana, B. 1987. Teknologi Pengemasan pangan. Laboraturium rekayasa proses pangan, PAU pangan dan gizi, IPB. Bogor.
WHO. 2010. Exposure to Benzene: A Major Public Health Concern. WHO Document Production Services, Geneva, Switzerland.

Wilmana, F.P., 2007. Farmakologi dan Terapi Edisi ke-5. Jakarta: Bagian Farmakologi Fakultas Kedokteran Universitas Indonesia.

Winarno, F.G., Jennie. 1982. Kerusakan Bahan Pangan dan Cara Pencegahannya. Ghalia Indonesia. Jakarta.

Zhou Z, Wang Y, Jiang Y, Diao Y, Strappe P, Prenzler P. 2016. DeepFried Oil Consumption In Rats Impairs Glycerolipid Metabolism, Gut Histology And Microbiota Structure. Lipids in Health and Diseas. 15:86. 